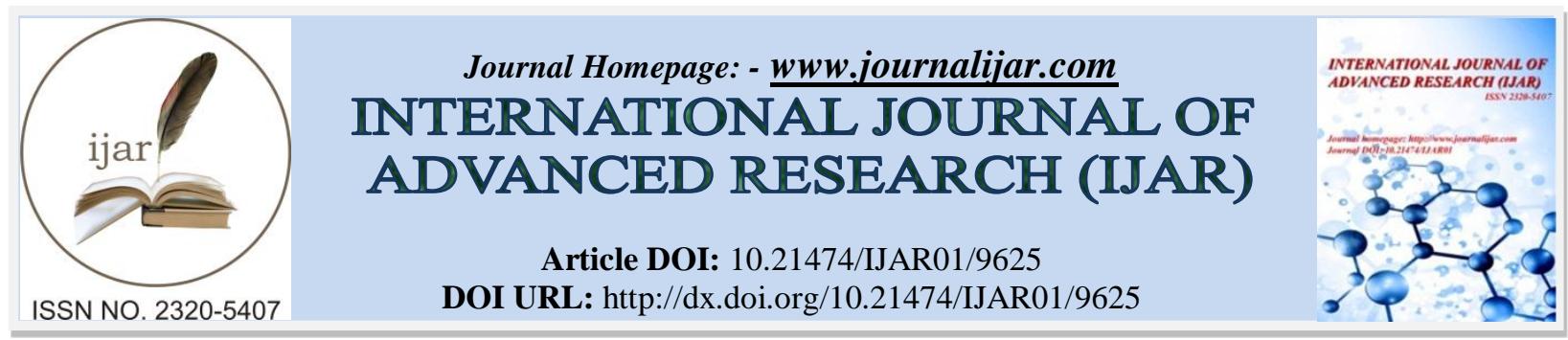

RESEARCH ARTICLE

\title{
DESIGN AND CONSTRUCTION OF A GREENHOUSE FOR EVALUATION OF THE PERFORMANCE OF OKRA IN THE SAHEL REGION OF ONDO STATE, NIGERIA.
}

Ale M. O. ${ }^{1}$, Akinyoola J. A. ${ }^{2}$, Fawohunre A. J. ${ }^{1}$ and Aderibigbe A.T.B ${ }^{3}$.

1. Department of Agricultural and Bio-Environmental Engineering Technology, Rufus Giwa polytechnic, owo.

2. Meterological Station, Department of Agricultural and Bio-Environmental Engineering Technology.

3. Department of Crop, Soil and Pest Management Technology Rufus Giwa Polytechnic, Owo.

\section{Manuscript Info}

Manuscript History

Received: 02 July 2019

Final Accepted: 04 August 2019

Published: September 2019

Key words:-

Greenhouse, design, construction, performance, okro.

\section{Abstract}

A 4.5 x $6.74 \mathrm{~m}$ greenhouse was designed and constructed at Rufus Giwa Polytechnic, Owo, Nigeria to evaluate the performance of okra under the greenhouse condition. The greenhouse consists of the frame, woven net and solarig cover of $170 \mathrm{gsm}$. Drib/bucket irrigation system with irrigation frequency of 2 times daily was used for the research. An experiment was conducted in the greenhouse during the dry season to determine the effects of greenhouse and liquid organic fertilizer on the performance of okra. In the experiment, a fertigation process was performed with varying quantities of the Super Gro liquid organic fertilizer, $0,20,40 \mathrm{ml}$ which were proportionally mixed with the irrigation water for each treatment. Daily measurement of the soil temperature was recorded and the morphological features were measured every week at the mid-flowering stage of the plant during the experiment. The results of the research reveal that the plant height was initially the same and later became higher in the greenhouse than the one in the control plot. The same observation was made on the leaf surface area of okra, but higher values were later observed in the control plot. The maximum leaf area recorded in the greenhouse was $0.76 \times 10^{3} \mathrm{~m}^{2}$ while the one in the control plot was $1.313 \times 10^{3} \mathrm{~m}^{2}$. There was no significant difference in the number of leaves in both the greenhouse and the control experiments in the first 2 weeks of the experiment but later became higher in the control plot. Higher percentage of $83.33 \%$ germination was recorded in the greenhouse against $58.33 \%$ of the control plot. Negative effect of the inorganic fertilizer on the yield of okra was observed as the yield decreased with increase in the quantity of fertilizer applied both in the greenhouse and the control plot. The results therefore show that greenhouse has the potential to improve the growth performance of okra. They also reveal that the inorganic fertilizer has no influence on the fruit yield of okra. It is recommended that this research should be repeated during the raining season for seasonal evaluation of the performance of okra in the greenhouse.

Copy Right, IJAR, 2019,. All rights reserved.

Corresponding Author:-Ale M. O.

Address:-Department of Agric. \& Bio-Environmental Engineering Technology. Rufus Giwa Polytechnic, Owo. 


\section{Introduction}

Climate change is a global issue that is not limited to a particular country and its impacts on the activities of man and his environment are now extremely felt in Nigeria. There are seasonal changes for every activity, especially in the area of rain-fed agriculture. If efforts are not taken at developing Protected Agriculture which is also known as Greenhouse farming, most of our tropical crops may go into extinction, especially the vegetables that are mostly consumed. If this happens, the level of the food production that is not sufficient will be reduced and the degree of hunger and poverty that was described as twin brothers by Oloyede (2011) will increase in the country. The impact of climate change has exposed Nigeria to long dry seasons. Nigerian climate is now characterized by a period of raining season from April-August and dry season period from September-March (Indeje et al, 2000). Recently, climate related disasters and the growing of climate change (Roudier et al., 2014) are indications that protective farming is necessary for optimum crop production.

Greenhouse farming optimizes the available resources like water, nutrients, energy, space, capital and labor, and thereby creates the desired plant product or biological processes (Murat, 2012). This can be made possible by erecting a greenhouse structure. By the design and construction, various materials like polythene and PVC have been used to replace glass to prevent trapping of terrestrial long wave radiation from earth surface (Prasad and Kumar 2014).

Generally, the attached and stand-alone greenhouse structures are the major types of greenhouse. Greenhouse should be located in the south or southeast side of a building or shade trees where it gets the maximum sunlight. Morning sunlight is most desirable as it allows the early phosynthesis that aids optimum growth of plant. An east side location captures the most November to February sunlight (Bucur, 2010).

The yields from greenhouse farming are 10 to 12 times higher than the one from the open farm system. Reliability of crop increases under greenhouse cultivation; suitability for vegetables and flower crops; year-round production of crops; and production of disease-free and genetically seedlings for transplants are other benefits of protected farming. With the benefits of Protected Agriculture(greenhouse), it is an alternative way of getting a solution the impact of the climate change on agricultural production. Therefore, this research was on the design and construction of a greenhouse for evaluation of the performance of okra ((abelmoschus esculentus L. moench) in Owo, a Sahel region of Ondo State, Nigeria.

\section{Materials and Methods \\ Experimental Site}

The site was located at the Teaching and Research Farm of Rufus Giwa Polytechnic, Owo, Nigeria (Lat $7^{0} 15^{\prime} \mathrm{N}$ Long. $5^{0} 35$ 'E) and Elevation, 210m. The soil was sandy loam in texture with 753, 127 and $120 \mathrm{~g}$ kg-1 sand, silt and clay, respectively (Agbede et al., 2018).

\section{Design Calculations}

\section{Area Covered by the Greenhouse}

The area covered by the greenhouse was determined as $30.33 \mathrm{~m}^{2}$ using equation 1

Area $=$ Lenght $\times$ Breadth

\section{Selection and Material Designs \\ Layout Design}

The greenhouse of $4.5 \times 6.74 \mathrm{~m}$ was designed for okra with spacing of $0.6 \times 0.6 \mathrm{~m}$. The okra was designed to grow on a raised bed of size $3.6 \times 4.2 \mathrm{~m}$ with a walkway of $0.45 \mathrm{~m}$ is kept by the two sides of the beds to carry crop maintenance operations.

\section{Determination of the Load of the Greenhouse}

The greenhouse was constructed with 1.5/1 inch galvanized pipes and 1-inch square pipe. The main frame was constructed with 1.5-inch pipe while the supports were constructed with 1-inch pipe. The greenhouse doors were constructed with 1-inch square pipe of mild steel. The load of the frame was determined as $1.484 \mathrm{kN}$ using the following equations;

$\operatorname{Mass}(\mathrm{kg})=$ Density $\times$ Volume

Volume of the Pipe $\left(m^{3}\right)=\frac{\pi D^{2} L}{4}-\frac{\pi d^{2} L}{4}$ 
Volume of the Square Pipe $\left(\mathrm{m}^{3}\right)=$ Length $\times$ Breadth $\times$ Height

Weight $(N)=$ Mass $\times$ Acceleration due to gravity

Density of steel is $7850 \mathrm{~kg} / \mathrm{m}^{3}$ (Khurmi and Gupta, 2013)

Irrigation Parameters and Space Design

\begin{tabular}{|l|l|}
\hline Crop & Okra \\
\hline Spacing & 0.6 X $0.6 \mathrm{~m}$ \\
\hline Number of Plants & 42 \\
\hline Irrigation System & Bucket/Drip \\
\hline Daily Evaporation/Rate & $39 \mathrm{~mm} / 1.62 \mathrm{~mm}$ \\
\hline Irrigation Frequency & 2 times daily \\
\hline Total Irrigation Time & 10 minutes per frequency \\
\hline Total Head & $1.2 \mathrm{~m}$ \\
\hline Length of the Lateral & $5 \mathrm{~m}$ \\
\hline Number of Rows per Treatment & 2 \\
\hline Volume of Bucket & 20 litres \\
\hline Fertiliser used & Super Gro Liquid Organic Fertilizer \\
\hline Fertilizer Treatment Ratio & $0: 1: 2$ \\
\hline Fertilizer Application Ratio & $1 \mathrm{ml} /$ litre of water \\
\hline
\end{tabular}

\section{Bucket Stand Design}

The weights of irrigation water per bucket and the bucket stand were determined as $206.01 \mathrm{~N}$ and $46.58 \mathrm{~N}$ respectively using equations 2,5 and 6 ;

Volume of Iron $\operatorname{Rod}\left(m^{2}\right)=\frac{\pi D^{2} L}{4}$

Density of Water, $\rho$ is $1000 \mathrm{~kg} / \mathrm{m}$

\section{Water Requirement for Okra/ Selection of irrigation Bucket}

The water requirement of crop was determined as 1.719 litres per day per plant using equation 7 (FAO, 2013). Therefore, for each stand, 27 litres of water was required per day per stand. There was a provision for the supply of 15 litres of water to each irrigation bucket twice daily for the experiment. A bucket with calibration of 20 litres in volume was therefore selected for the experiment.

$W R=A \times B \times C \times D \times E$

Where:

WR is Water requirement ( $1 \mathrm{p} \mathrm{d} /$ plant); A, Open Pan evaporation is $0.0274 \mathrm{~mm}$ per day $/ 8.3 \mathrm{~mm}$ per year (Oguntunde et al., 2011); B is Pan factor (0.7); this may differ area wise; C is Spacing of plant $\left(\mathrm{m}^{2}\right)$; D is Crop factor (factor depends on plant growth-for fully grown plants $=1)$; E is the Wetted Area ( 0.3 for widely spaced crops)

The total water requirement of the farm plot would be WR x Number of Plants.

\section{Selection and Design of Irrigation Lines}

On the layout, there were three irrigation buckets of six beds, each bucket controls 2 beds on each bed. There were eight drippers on each bed of $5000 \mathrm{~mm}$ with crop spacing of $600 \mathrm{~mm}$. Other features for the selection of the drippers for the okra were as follows;

Number of plant per row was 8 ; total number of plant in the greenhouse is 48 ; water requirement per day per plant is 1.719 litres; total water requirement per day, $\mathrm{V}$ was 82.512 litres; total number of drippers per lateral is 8 ; irrigation duration(V/Q) is 52 minutes ( 0.86 hours); number of drippers per experimental stand is 16.

\section{Capacity of the Irrigation System, Q}

The capacity of the irrigation system was determined as 96 litres per hour using equation 8( Sharan and Jadhav, 2002)

$Q=$ no of drippers $\times$ dripper discharge

Dripper discharge for non-pressure compensating on line drippers is 2-4 litres per hour. 


\section{Design and Selection of the Laterals}

According to Sharan and Jadhav (2002), for a drip irrigation system in which not more than $20 \%$ of pressure variation and $10 \%$ flow variation are desirable, the head loss $\left(\mathrm{H}_{\mathrm{f}}\right)$ in lateral, sub-main and main lines was determined using equation 9 .

$H_{f}=1.526 \times 10^{4} \times \frac{Q^{1.852}}{C} \times D^{-4.873} \times L \times f$

For the lateral, the discharge, $\mathrm{Q}$ was determined as 16 litres using equation 10.

$Q=\frac{L_{i}}{S_{j}} \times Q_{j}$

Roughness irrigation coefficient C.F is 140 .

Allowable head loss in lateral and submain $=2 \mathrm{~m}$, of this, $1.4 \mathrm{~m}$ is kept for head loss in lateral and $0.6 \mathrm{~m}$ for submain. Using equation (9) for lateral design, the Diameter of the pipe D was determined as $5.704 \mathrm{~mm}$. Minimum lateral pipe size available in market is $12 \mathrm{~mm}$ with internal diameter $9.8 \mathrm{~mm} .12 \mathrm{~mm}$ lateral pipe was therefore selected for the laterals.

Going back to equation (9) with appropriate substitution for lateral of $12 \mathrm{~mm}, \mathrm{H}_{\mathrm{f}}=0.0381 \mathrm{~m}$

\section{Design and Selection of the Sub-main}

There are 2 laterals on one sub-main, therefore, the discharge, $Q_{s}=0.016 \times 2=0.032 \mathrm{~m}^{3} / \mathrm{hr} ; H_{f s}=0.6 \mathrm{~m} ; C_{s}=$ 140

Using equation 9, the diameter of the sub-main pipe was determined as $9.447 \mathrm{~mm} .12 \mathrm{~mm}$ pipe was selected for the sub-main pipes.

\section{Fabrication and Assembly of the Greenhouse}

A greenhouse (Fig 1 and 2) was fabricated and assembled at Rufus Giwa Polytechnic using galvanized pipes of $37.5 \mathrm{~mm}$ (1.5 inches) and $25 \mathrm{~mm}$ (1 inch) diameters; solarig cover (170 gsm) and woven net round the lower sides $(1000 \mathrm{~mm})$ above the ground level and doors $(2700 \mathrm{~mm} \times 1130 \mathrm{~mm})$ of the greenhouse. The greenhouse components (the beam, the supports and the roof materials were installed on a reinforced foundation. The beams, the roof laterals and the supports were joined together with the use of bolts and nuts. The greenhouse cover was appropriately shown on the structure.

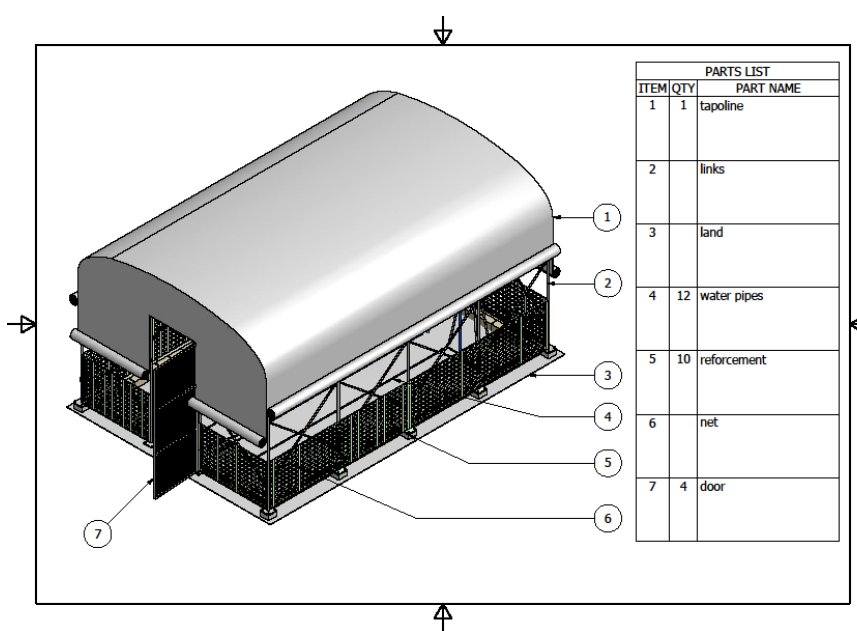

Fig 1:-Isometric View of the Greenhouse

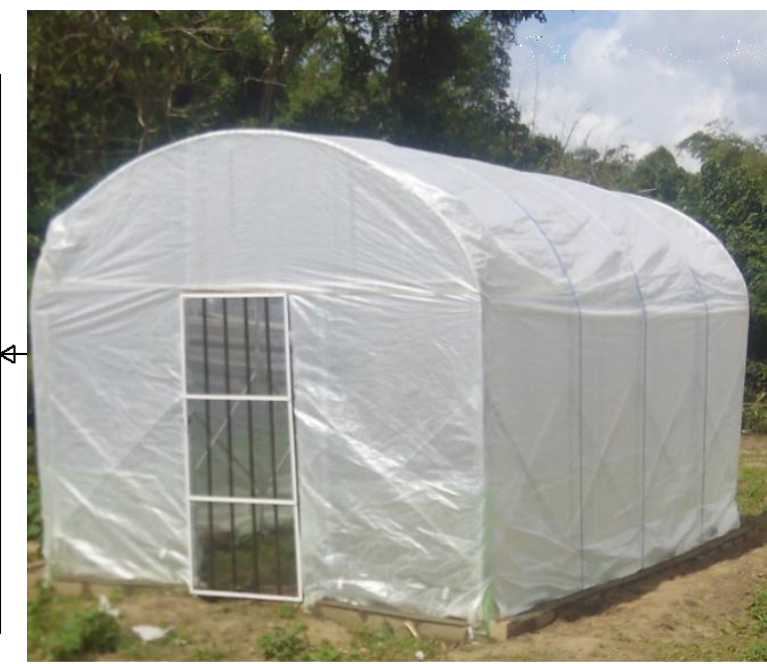

Fig 2:-The Constructed Greenhouse

\section{Installation of the Irrigation Facilities}

The irrigation pipes (laterals and sub-mains), the bucket stands and the buckets were installed on a flat bed. PVC pipes of $12 \mathrm{~mm}$ diameter was selected based on the designs used for both the laterals and the sub-mains of the three bucket stands in the greenhouse and the control plot as presented in Fig 3. There are 8 dripping points on each lateral. Each irrigation bucket (20 litres) which was manually filled supplied water to a sub-main with 2 laterals. Other facilities provided in the greenhouse centre is a well, 1 horsepower pumping machine, water tower and a 1200 litres water tank with a water filter. 


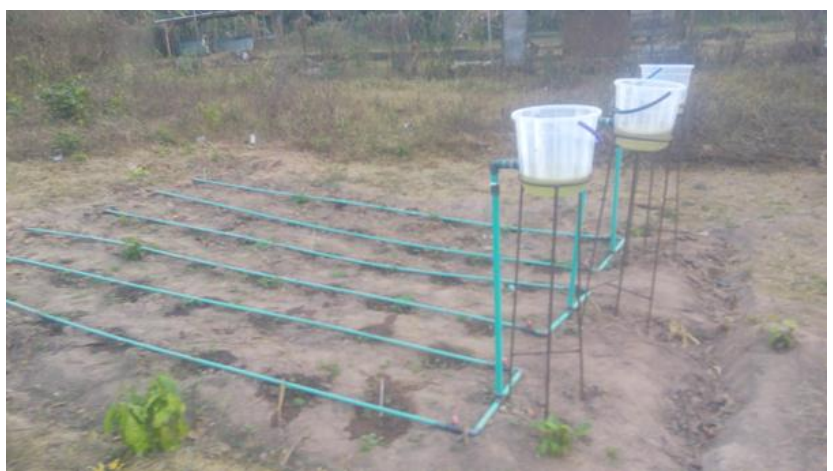

Fig 3:-Pictorial View of the Irrigation System (Control)

\section{Experimental Test and Methods}

The experimental test was carried out inside the greenhouse with a controlled plot outside the greenhouse for comparison. The plant used for the experiment was okra (abelmoschus esculentus L. moench). The experiment was to determine the effects of the greenhouse and liquid organic fertilizer (Super-Gro) on the growth and yields of okra. Okra plants were planted directly beside the dripping points of the laterals at an inter-row spacing of $60 \mathrm{~cm}$ and a 60 $\mathrm{cm}$ intra-row spacing providing 16 plants per treatment, making 48 okra plants.

In the experiment, varying quantity of the fertilizer; 0,20 and $40 \mathrm{ml}$ were applied by mixing it appropriately with the water inside the irrigation bucket for each treatment. The soil temperature was measured daily using soil thermometer and the morphological features of the okra plants were measured weekly to determine the variations in the growth rate of the plants per treatment. For the measurement, 4 plants were randomly selected per treatment for evaluation of the plant height, number of leaves and leaf area at the mid-flowering stage. Number of leaves were measured by manual counting and leave area (A) was estimated using the mathematical model (equation 11) developed by Lyon (1948) as reported by Agbede et al. (2018). The plant height was measured from the base of the plant to the shoot using a meter rule.

$A=K L^{2}$

where $\mathrm{A}$ is the leave area; $\mathrm{K}$ is the constant and $\mathrm{L}$ is the length of the leave.

The number of fruits and fruit yield were evaluated between $5^{\text {th }}$ and $7^{\text {th }}$ week after planting. The fruit yields were evaluated based on the cumulative harvests per treatment. Fruits were counted and fresh weight obtained using an electronic loading balance (Superior Mini-Digital Platform Scale- China). Before the start of the experiment, the soil bulk density was determined as using equation 12; Soil samples were collected for the particle size distribution/textural class determination.

Soil Bulk Density $=\frac{\text { Mass of Oven Dried Soil }}{\text { Volume of the Soil }}$

\section{Results and Discussions:- \\ Results}

The results of the evaluation test of the greenhouse for okra production are presented in Fig 4, 5, 6,7 and 8 


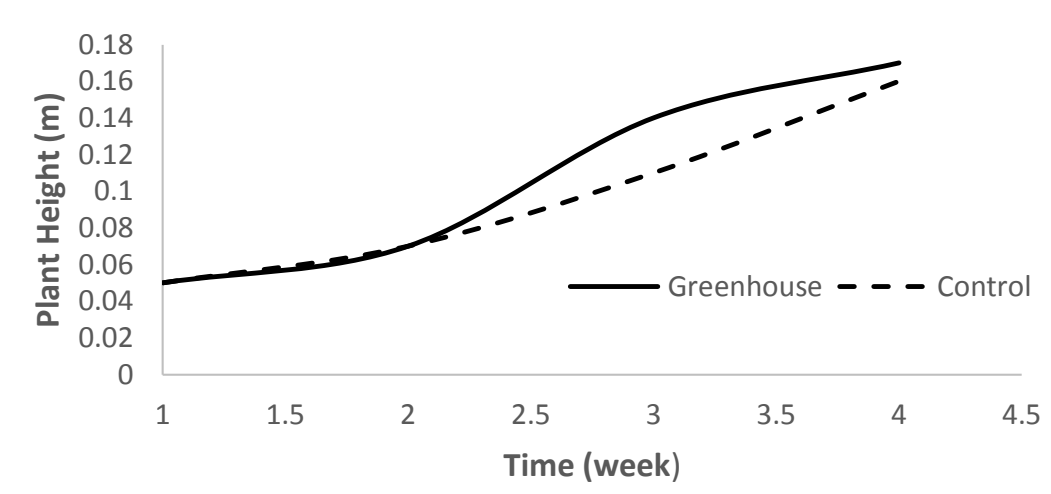

Fig 4:-Effect of Greenhouse on the Plant Height of Okra

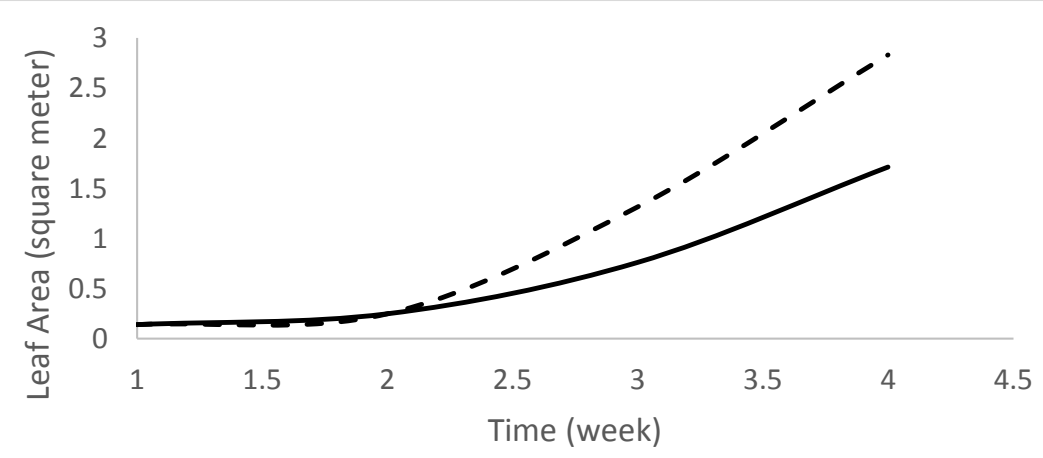

Greenhouse - - - Control

Fig 5:-Effect of Greenhouse on the Leaf Area of Okra

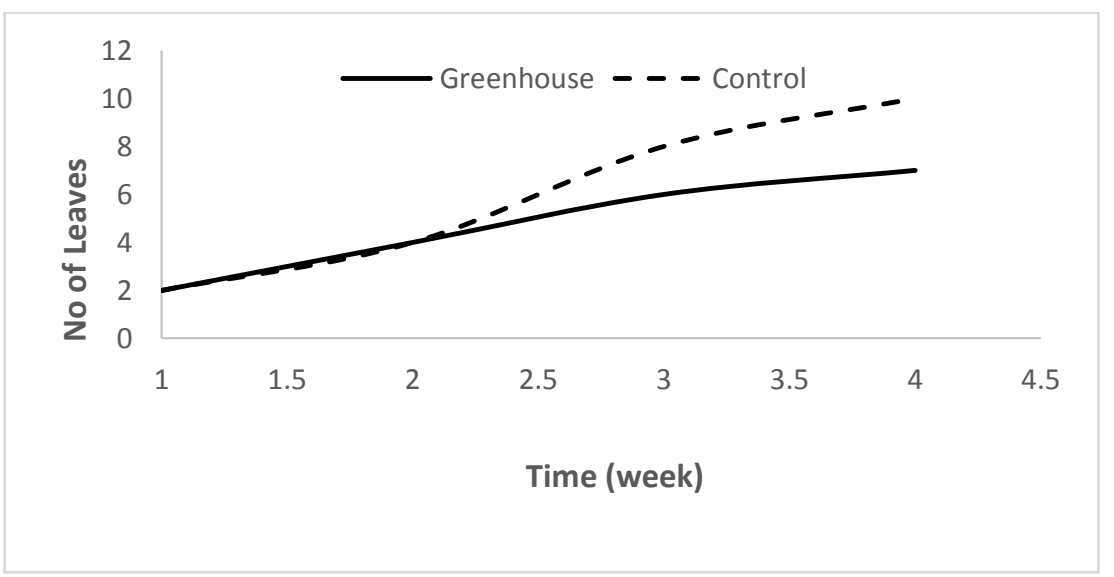

Fig 6:-Effect of Greenhouse on the Number of Leaves of Okra 


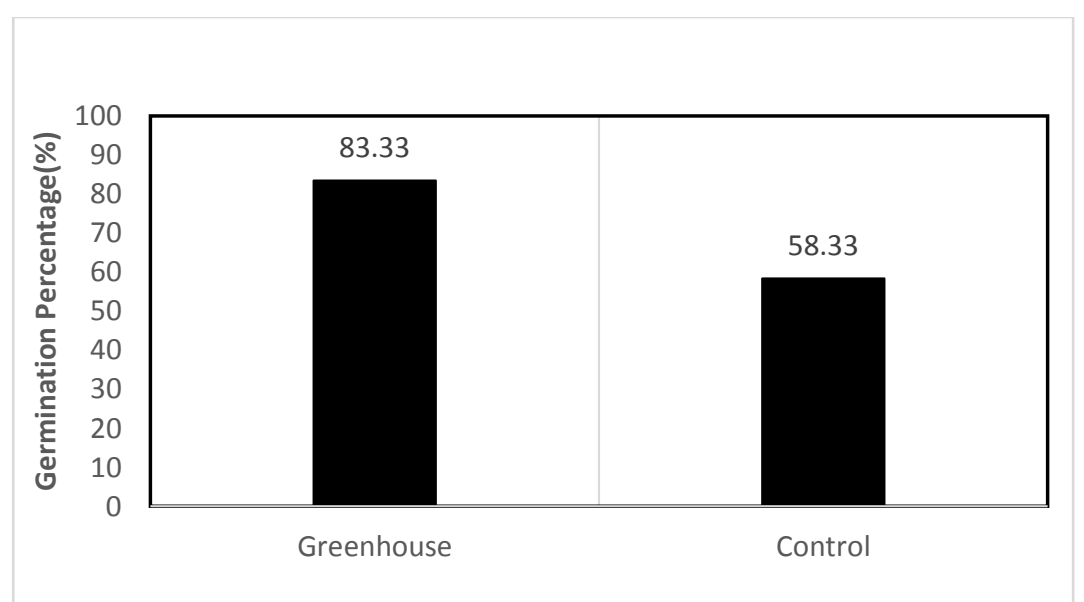

Fig 7:-Effect of Greenhouse on the Germination Percentage of Okra

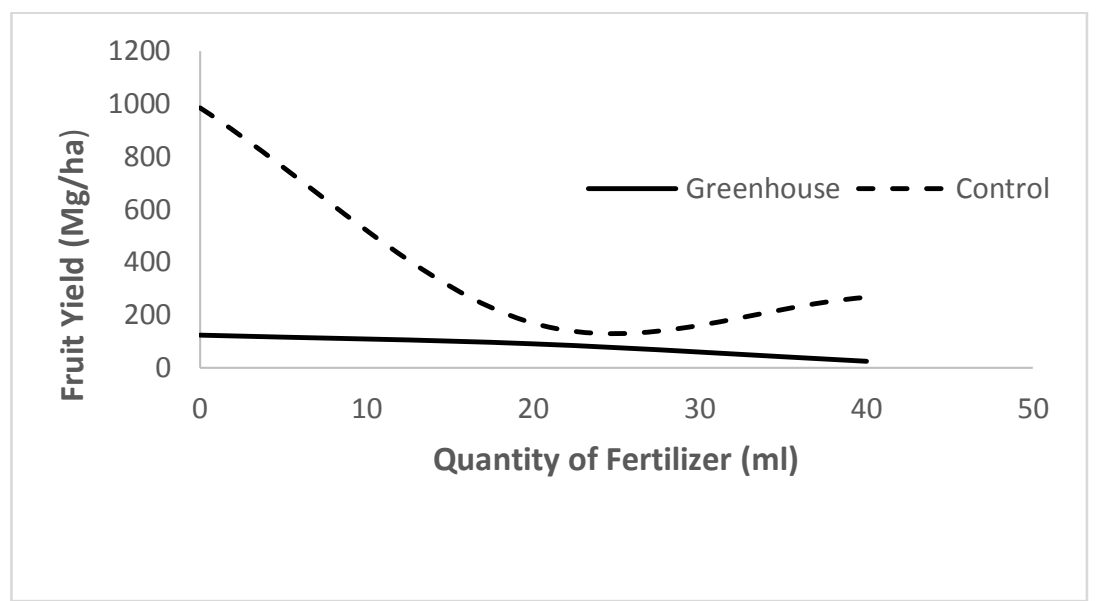

Fig 8:-Effect of Fertilizer Volume on the Yield of Okra

\section{Discussions:-}

\section{Greenhouse and the Growth Rate of Okra}

As presented in Fig 4, the plant height of okra in the greenhouse and the control plot were initially the same and increased with time at the same rate but the height of plant in the greenhouse became higher than the ones in the control plot. The minimum height of the plant recorded during the experiment was $0.05 \mathrm{~m}$ after 1 week of planting both in the greenhouse and in the control plot. While the maximum height was $0.17 \mathrm{~m}$ in the greenhouse and $0.16 \mathrm{~m}$ in the control plot after 4 weeks of planting before the fruiting stage. This was due to the higher temperature of the greenhouse. This is in conformity with the report by Akinyoola et al. (2013) that reported that leaf number of plants increased with increase in temperature.

Same effect was observed with the surface area of the leaf of okra, but higher values were later observed in the control plot (Fig 5). This may be as a result of the increase in humidity in the greenhouse that was caused by the increase in the vegetative cover from the okra plants. The maximum leaf area recorded in the greenhouse was $0.76 \mathrm{x}$ $10^{3} \mathrm{~m}^{2}$ while the one in the control plot was $1.313 \times 10^{3} \mathrm{~m}^{2}$.

In Figure 6, the reverse is the case with the relationship between the greenhouse and the number of leaves per week of the okra plant. In the first 2 weeks, the number of leaves increased at the same rate but the number of leaves of the plants in the control plot later became higher.

\section{Greenhouse and the Germination Percentage of Okra}

Wide variation was observed in the germination percentage of okra in the evaluation test of the greenhouse (Fig 7). In the experiment, $83.33 \%$ germination was recorded in the greenhouse against $58.33 \%$ of the control plot. This 
was as a result of higher soil temperature of the greenhouse which varies between 27 and $30^{\circ} \mathrm{C}$. This is in conformity with Nasser et al. (1981) and Dalorima et al. (2014) that reported that plants grow at high soil temperature.

\section{Quantity of Liquid Organic Fertilizer and the Fruit Yield of Okra}

As presented in Fig 8, the liquid organic fertilizer on the fruit yield of okra is negative as the yield decreased with increase in the quantity of fertilizer applied, both in the greenhouse and the control plot. Though, higher yields were recorded from the control plot with the yield of $983.7 \mathrm{Kg} / \mathrm{ha}$ and average of 9 fruits per plant. The maximum yield recorded in the greenhouse was $122 \mathrm{Kg} / \mathrm{ha}$ and 3 fruits per plant. This is contrary to Agbede et al. (2018) that reported that the use of green manure and NPK fertilizer improved the yield and other morphological parameters of tomatoes in their study on the effects of green manure and NPK fertilizer of tomatoes production.

\section{Conclusions:-}

A greenhouse was designed and fabricated with drip/bucket irrigation facilities for evaluation of the performance of okra in the Sahel region of Ondo State, Nigeria. The experiment was conducted to evaluate the performance of okra. Satisfactory germination percentage was recorded in the greenhouse with good correlation between the greenhouse and the morphological characteristics of okra. While a negative correlation was observed between the fertilizer volume and the fruit yield of okra.

\section{References:-}

1. Agbede T. M., Adekiya, A. O., Ale, M. O., Elfediyi E. K. and Olatunji C. A. (2018). Effects of Green Manures and NPK Fertilizer on Soil Properties, Tomato Yield and Quality in the Forest-Savanna Ecology of Nigeria. Expl Agric.: page 1 of 14 C _ Cambridge University Press 2018

2. Akinyoola, J. A., Ologunagba F. O. and Omonijo O. G. (2013). Microclimate Factors for Sustenance and Optimum Crop Production in Greenhouse System. IOSR Journal of Agriculture and Veterinary Science (IOSR-JAVS). 2 (1): 39-44. www.iosrjournals.org

3. Bucur R. D (2010). Greenhouse Project Construction and Planning Design. Universitatec de Stiinte, Agricole Si Medicina Veterinanra Lasi 53 (1): 187-190.

4. Daloima L. T., Bunu A., Kyari Z. and Mohammed T. (2014). Effects of Different Mulching Materials on the Growth Performance of Okra in Maiduguri. International Journal of Agricultural Science and Soil Science. 4(8):145-149

5. FAO (2013). Good Agricultural Practices for Greenhouse for vegetable crops- Principles forMediterranean Climate Areas; FAO Plant Production and Protection. Paper 217. www.fao.org/publications

6. Indeje, M., Semazzi, H. and Ogallo, J., (2000) " ENSO Signals in East African Rainfall Seasons," International Journal of Climatology, pp. 19-46,

7. Khurmi R. S and Gupta J. K. (2013). Design of machineelements."Eurasia Publishing House(pvt.)Ltd,fivthedition.

8. Lyon, C. J. (1948). A factor method for the leaf area of tomato leaves. Plant Physiology 23(4):634-635.

9. Murat, K. (2012). Greenhouse Structures and Design. UA-CEAC Greenhouse Crop Production \& Engineering Design Short Course.

10. Nasser, S., Strain B. R. and Backford H. A. (1981). Environmental Controls on the Growth and Yield of Okra; Effects of Temperature and $\mathrm{CO} 2$ Enrichment at Cool Temperature. Alliance of Crop, soil and Environment Science Societies- Digital Library. 21 (6): 885- 888.

11. Oloyede, I. O. (2011). "Poverty is Preventable". Text of address delivered by the Vice Chancellor of the University of Ilorin at the opening of the symposium of International Soil Tillage Research Organisation, Nigeria on February 22, 2011 at the university auditorium

12. Prakash O., and Kumar A. (2014), "Solar greenhouse drying: A review", Renewable and sustainable Energy Reviews, 29: pp 905-910.

13. Roudier P. Muller B., d'Aquino P., Roncoli C., Soumare L., Batte L. and Sultan B. (2014). The Role of Climate Forecasts in smallholder Agriculture: Lessons from participatory Research in Two Communities in Senegal. Climate Risk Management. 2: $42-55$.

14. Sharan G., and Jadhav R. (2002). Design of Greenhouse Irrigation System at Khothara. www.researchgate.net 